South Dakota State University

Open PRAIRIE: Open Public Research Access Institutional

Repository and Information Exchange

3-2019

Nitrogen Demand Associated with Increased Biomass Yield of

Switchgrass and Big Bluestem: Implications for Future Breeding

Strategies

Michael D. Casler

DoKyoung Lee

Robert B. Mitchell

Paul R. Adler

R. Mark Sule

See next page for additional authors

Follow this and additional works at: https://openprairie.sdstate.edu/nativeplant_pubs

Part of the Ecology and Evolutionary Biology Commons, and the Plant Sciences Commons 
Authors

Michael D. Casler, DoKyoung Lee, Robert B. Mitchell, Paul R. Adler, R. Mark Sule, Keith D. Johnso, Robert Kallenbach, Arvid A. Boe, Russell D. Mathison, Kim A. Cassida, Doohong Min, and Kenneth J. Moore 


\title{
Nitrogen Demand Associated with Increased Biomass Yield of Switchgrass and Big Bluestem: Implications for Future Breeding Strategies
}

\author{
Michael D. Casler ${ }^{1}$ (D) DoKyoung Lee ${ }^{2} \cdot$ Robert B. Mitchell $^{3} \cdot$ Paul R. Adler $^{4} \cdot$ R. Mark Sulc ${ }^{5} \cdot$ Keith D. Johnson $^{6} \cdot$ \\ Robert L. Kallenbach ${ }^{7}$. Arvid R. Boe ${ }^{8} \cdot$ Russell D. Mathison $^{9} \cdot$ Kim A. Cassida $^{10} \cdot$ Doohong Min $^{11} \cdot$ Kenneth J. Moore $^{12}$
}

Published online: 5 December 2019

(C) This is a U.S. Government work and not under copyright protection in the US; foreign copyright protection may apply 2019

\begin{abstract}
Development of perennial biomass cropping systems is focused on maximizing biomass yield with minimum inputs, particularly nitrogen $(\mathrm{N})$ fertilizer. Historical breeding efforts have focused on increasing biomass yield but have ignored N-use efficiency. The purpose of this study was to quantify the increased $\mathrm{N}$ demand associated with realized gains in biomass yield from big bluestem (Andropogon gerardii Vitman) and switchgrass (Panicum virgatum L.) breeding programs. Nitrogen demand was highly variable across locations and years, ranging from -1.7 to $+6.8 \mathrm{~kg} \mathrm{~N} \mathrm{Mg}^{-1} \mathrm{DM}$, with an average of $2.2 \mathrm{~kg} \mathrm{~N} \mathrm{Mg}^{-1} \mathrm{DM}$. Increases in $\mathrm{N}$ demand were closely associated with realized gains in biomass yield and were observed for all types of switchgrass (upland, lowland, and hybrid) as well as for big bluestem. Attenuation of these responses will require alternative breeding schemes that are focused on evaluation of switchgrass genotypes and progeny under low-N conditions and include a highthroughput tissue $\mathrm{N}$ analysis as a component of future selection criteria, designed to develop new cultivars with high biomass yield and low tissue $\mathrm{N}$.
\end{abstract}

Keywords Panicum virgatum L. · Andropogon gerardii Vitman · Nitrogen-use efficiency · Breeding · Genetics

\section{Introduction}

Development of sustainable perennial grass production systems is a key element of many proposed cellulosic biomass systems [1]. Switchgrass has been the model herbaceous species for these systems since 1992 [2]. Although it receives considerably less attention and funding, big bluestem is also a candidate for biomass production, owing to high yield in

Electronic supplementary material The online version of this article (https://doi.org/10.1007/s12155-019-10081-y) contains supplementary material, which is available to authorized users.

Michael D. Casler

michael.casler@usda.gov; mdcasler@wisc.edu

1 USDA-ARS, U.S. Dairy Forage Research Center, 1925 Linden Dr, Madison, WI 53706-1108, USA

2 Department of Crop Sciences, University of Illinois, Urbana, IL 61801, USA

3 USDA-ARS, Wheat, Sorghum, and Forage Research Unit, 251 Filey Hall, University. of Nebraska, Lincoln, NE 88583-0937, USA

4 USDA-ARS, Pasture Systems and Watershed Management Research Unit, University Park, PA 16802, USA

5 Department of Horticulture and Crop Science, The Ohio State University, Kottman Hall, Columbus, OH 43210, USA
6 Department of Agronomy, Purdue University, West Lafayette, IN 47907, USA

7 Division of Plant Sciences, University of Missouri, Columbia, MO 65211, USA

8 Department of Plant Science, Agricultural Hall, South Dakota State University, Brookings, SD 57007, USA

9 North Central Research \& Outreach Center, University of Minnesota, Grand Rapids, MN 55744, USA

10 Department of Plant Soil and Microbial Sciences, Michigan State University, East Lansing, MI 48824, USA

11 Department of Agronomy, Kansas State University, Manhattan, KS 66506, USA

12 Department of Agronomy, Iowa State University, Ames, IA 50011, USA 
monocultures and candidacy as a component of high-diversity biomass polycultures [3, 4]. The general strategy for producing high-diversity polycultures is similar to that used to develop high-yield forage mixtures: select the highest-yielding cultivars of each species, each developed by breeding for high biomass yield and adaptation to the desired target population of environments $[5,6]$. The best mixtures or polycrosses are then likely to be derived from the best components available.

Breeders have been extremely successful increasing biomass yield of switchgrass and, to a lesser extent, big bluestem. Genetic gains in biomass yield have been documented from several breeding programs $[7,8]$. These and earlier studies have documented the strong genotype $\times$ environment $(\mathrm{GE})$ interactions that exist for switchgrass, primarily associated with temperature and photoperiod, secondarily associated with moisture availability across a longitudinal gradient, and occasionally associated with soil characteristics [9]. These interactions appear to exist for big bluestem as well but are not as well characterized as for switchgrass $[9,10]$. These studies have been critical in determining adaptation zones for individual cultivars and for helping to define the most efficient breeding methods to develop more broadly adapted cultivars.

Despite these gains and advancements, the role of $\mathrm{N}$ fertilizer in both commercial production systems and in breeding nurseries remains hotly debated and largely unresolved [1, 11]. Removal of $\mathrm{N}$ from the system is one of the major disadvantages of $\mathrm{N}$ fertilization. Increased rates of $\mathrm{N}$ fertilizer lead to increased nitrous oxide emissions, increased nitrate leaching, increased $\mathrm{N}$ removal in harvested biomass, and decreased $\mathrm{N}$-use efficiency $[1,12,13]$. Furthermore, switchgrass biomass yield responds to increased $\mathrm{N}$ fertilizer only in about $50 \%$ of published N-rate experiments [14].

The purpose of this study was to determine the extent to which increases in biomass yield associated with breeding gains during the past 30 years have led to increased $\mathrm{N}$ demand for biomass crops of switchgrass and big bluestem. The experiments were conducted under "optimal" nitrogen conditions, using a fertilization rate of $112 \mathrm{~kg} \mathrm{ha}^{-1}$ as recommended by Vogel et al. [15]. As such, the results and conclusions are intended to be focused on soil for which nitrogen is nonlimiting for growth and biomass accumulation.

\section{Materials and Methods}

\section{Field Sites and Plant Materials}

Switchgrass and big bluestem field experiments were planted at 13 locations in April or May 2012 and 2014 [8]. Experiments planted in 2012 included 22 switchgrass populations and 12 big bluestem populations. Eight of the switchgrass populations planted in 2012 were proprietary and bred outside of the North Central region, so they were not used in computing any of the statistical comparisons described later. Data from these eight populations were used in the analyses of variance for the sake of completeness and to improve the power of hypothesis tests. Experiments planted in 2014 included 20 switchgrass populations and 11 big bluestem populations [8], all of which were used for data analysis and included in the statistical data analyses reported herein.

Each experiment was designed as a randomized complete block with four replicates and plot sizes that varied with location, depending on local equipment and preferences, with details of the locations in Table 1 [16] and details of the populations in Tables 2 and 3 [8]. All plots were established with either 5-row or 7-row drill planters (0.9-m or 1.2-m width) at a seeding rate of 600 pure live seeds per meter squared. Germination percentages [17], and 1000-seed mass were used to adjust seeding rates to a pure-live-seed basis. Preemergence herbicide treatments were $0.56 \mathrm{~kg} \mathrm{ha}^{-1}$ quinclorac [3,7-dichloroquinoline-8-carboxylic acid] plus $1.1 \mathrm{~kg} \mathrm{ha}^{-1}$ atrazine [1-chloro-3-ethylamino-5-isopropylamino-2,4,6-triazine] for switchgrass or $0.28 \mathrm{~kg} \mathrm{ha}^{-1}$ imazamethapyr [3pyridinecarboxylic acid, 2-(4,5-dihydro-4-methyl-4-(1methylethyl)-5-oxo-1H-imidazol-2-yl)-5-methyl-] for big bluestem. All 2012 plantings were successfully established, except for the big bluestem trial at Brookings, SD. In 2014, trials at Brookings, $\mathrm{SD}$, and all three Wisconsin locations, plus the big bluestem trial at Chatham, MI, failed to establish due to severe weed pressure. Of these, the only trial to recover was the 2014 switchgrass trial at Spooner, WI, which was delayed by 1 year due to slow establishment. The 2014 big bluestem trial at South Charleston, $\mathrm{OH}$, was not harvested due to severe lodging which prevented accurate yield measurements.

\section{Data Collection}

Plots were fertilized at a rate of $112 \mathrm{~kg} \mathrm{~N} \mathrm{ha}^{-1}$ in early spring, prior to initiation of growth, of each harvest year. Plots were mechanically harvested about 7 to 20 days after killing frost for up to 4 years (2012 trials) or 2 years (2014 trials). Harvesting was accomplished with either a sickle-bar mower or flail chopper, depending on location. Plot sizes and harvested areas varied across locations, but an unharvested border area was always preserved between plots [8]. A dry matter sample of 200 to $500 \mathrm{~g}$ was hand-clipped from random positions within each plot immediately before harvesting, and its mass was added to the recorded plot mass for completeness. Samples were dried for a minimum of 5 days at 55 to $65^{\circ} \mathrm{C}$ and used to compute dry matter concentrations and adjusting plot mass to a dry matter basis. Samples were ground through a 1-mm screen on a Wiley-type mill, shipped to Madison, WI, and scanned on a near-infrared reflectance spectrophotometer (NIRS). Nitrogen concentration was predicted using calibrations from a broad-based population of switchgrass biomass samples [18]. Nitrogen removal $\left(\mathrm{kg} \mathrm{ha}^{-1}\right)$ was computed as 
Table 1 Site characteristics of 13 field locations used to evaluate selected switchgrass and big bluestem populations

\begin{tabular}{|c|c|c|c|c|}
\hline Location & $\begin{array}{l}\text { Latitude } \\
{ }^{\circ} \mathrm{N}\end{array}$ & $\begin{array}{l}\text { Longitude } \\
{ }^{\circ} \mathrm{W}\end{array}$ & USDA plant $\mathrm{HZ}^{\mathrm{a}}$ & Soil type and taxonomy \\
\hline Grand Rapids, MN & 47.18 & 93.53 & $3 b$ & $\begin{array}{l}\text { Itasca-Goodland sandy loam } \\
\text { (coarse-loamy, mixed, superactive, frigid Haplic Glossudalf) }\end{array}$ \\
\hline Spooner, WI & 45.80 & 72.87 & $4 \mathrm{a}$ & Murrill silt loam (fine-loamy, mixed, mesic Typic Hapludult) \\
\hline Marshfield, WI & 44.65 & 90.13 & $4 \mathrm{~b}$ & Withee silt loam (fine-loamy, mixed, superactive frigid Aquic Glossudalf) \\
\hline Brookings, SD & 44.37 & 96.80 & $4 \mathrm{~b}$ & $\begin{array}{l}\text { McIntosh silt loam (fine-silty, mixed, superactive, frigid Aquic Calciudoll); } \\
\text { Badger silty clay loam (fine, smectitic, frigid Vertic Argiaquoll) }\end{array}$ \\
\hline Chatham, MI & 46.32 & 86.92 & $4 \mathrm{~b}$ & Eben very cobbly sandy loam (sandy-skeletal, mixed, frigid Pachic Hapludoll) \\
\hline Arlington, WI & 43.33 & 89.38 & $5 \mathrm{a}$ & Plano silt loam (fine-silty, mixed, mesic Typic Argiudoll) \\
\hline Ames, IA & 42.01 & 93.74 & $5 \mathrm{a}$ & Webster silty clay loam (fine-loamy, mixed, superactive, mesic Typic Endoaquoll) \\
\hline Mead, NE & 41.17 & 96.42 & $5 \mathrm{~b}$ & $\begin{array}{l}\text { 2012: Tomek silt loam (fine, smectitic, mesic Pachic Argiudoll) 2014: Filbert silt loam } \\
\text { (fine, smectitic, mesic Vertic Argialboll) }\end{array}$ \\
\hline Urbana, IL & 40.07 & 88.21 & $5 b$ & Drummer silty clay loam (fine-silty, mixed, superactive, mesic Typic Endoaquoll) \\
\hline West Lafayette, IN & 40.30 & 86.89 & $5 \mathrm{~b}$ & $\begin{array}{l}\text { Toronto silt loam (fine-silty, mixed, superactive, mesic Udollic Epiaqualf); } \\
\text { Millbrook silt loam (fine-silty, mixed, superactive, mesic Udollic Endoaqualf) }\end{array}$ \\
\hline Columbia, MO & 38.09 & 92.18 & $6 a$ & Mexico silt loam (fine, smectitic, mesic Vertic Epiaqualf) \\
\hline South Charleston, $\mathrm{OH}$ & 39.86 & 83.67 & $6 \mathrm{a}$ & $\begin{array}{l}\text { 2012: Crosby silt loam (fine, mixed, active, mesic Aeric Epiaqualf) 2014: } \\
\text { Kokomo silty clay loam (fine, mixed, superactive, mesic Typic Argiaquoll) }\end{array}$ \\
\hline State College, PA & 40.72 & 77.94 & $6 b$ & Hagerstown silt loam (fine, mixed, semiactive, mesic Typic Hapludalf) \\
\hline
\end{tabular}

${ }^{\text {a }}$ USDA plant hardiness zone [16]. Each location is shown on a map in Fig. 1 of [8]

the product of biomass yield $\left(\mathrm{Mg} \mathrm{ha}^{-1}\right)$ and nitrogen concentration $\left(\mathrm{mg} \mathrm{g}^{-1}\right.$ or $\left.\mathrm{kg} \mathrm{Mg}^{-1}\right)$.

\section{Statistical Data Analysis}

Data were analyzed separately by location and species. Locations were maintained as a "sort" variable rather than an ANOVA factor, because of the large range in USDA plant hardiness zones (PHZ; zones 3 to 6; Table 3) and the anticipated impact of this effect on the results of fixed-effect comparisons among populations. Mixed models analysis of variance was used with harvest year as a repeated measure and a compound symmetry covariance structure with either homogeneous or heterogeneous variances, whichever fit best according to Akaike's Information Criterion [19]. Block and planting year were considered random effects, while population and harvest year were fixed effects, the latter decision due to the large impact of stand age at some locations.

Statistical comparisons among populations were focused strictly on estimation and testing of gains from selection during the past 30 years, using five different measures of gain. Summer-Late-Mat-C2 was compared with summer switchgrass, both of which were present in both 2012 and 2014 plantings (Table 2). Four WS4U-derived populations were compared with WS4U using data from only the 2014 plantings (Table 2). Three groups of improved switchgrass populations were compared with each other, essentially excluding the natural populations and forage cultivars: improved lowland populations and improved populations derived from
Kanlow $\times$ Summer hybrids were both compared with improved upland populations (Table 2). Improved upland populations are not the ideal control for the other two groups, but they were used because the unimproved lowland populations, including Kanlow, are not sufficiently adapted to PHZ 3 through 5 to have reasonable survival levels. Furthermore, improved upland populations represent an opportunity cost of breeding locally adapted germplasm vs. adapting "exotic" germplasm that has traits not present in local ecotypes. It is still not completely clear if breeding efforts in these regions should be focused on upland, lowland, or hybrid sources of germplasm. Lastly, improved biomass-type big bluestem populations were compared with big bluestem cultivars (Table 3 ). Detailed results of these statistical comparisons for biomass yield were reported by [8], with partial results repeated here only to assist in explaining changes in nitrogen demand.

The latter two groups of comparisons were not perfectly balanced between the 2012 and 2014 plantings due to changes in the specific populations included in the trials, but the results of these comparisons were sufficiently similar between the 2012 and 2014 plantings that they could be pooled across plantings without any significant loss of information. Most of the reason for the imbalance between the 2012 and 2014 plantings is the essential purpose of repeated plantings of regional trials, to allow the newest and most recent candidate cultivars to be tested in a timely manner, of which there were numerous candidates produced in 2012 and 2013.

All statistical comparisons were computed as contrasts within mixed models analyses combined over 2012 and 
Table 2 Names, origins, and breeding histories of switchgrass populations planted in 2012 or 2014 experiments

\begin{tabular}{|c|c|c|c|c|c|}
\hline Population & Year $^{\mathrm{a}}$ & Origin $^{b}$ & Ecotype $^{\mathrm{c}}$ & Type $^{\mathrm{d}}$ & Breeding history \\
\hline Cave-in-Rock (CIR) & 2012, 2014 & Illinois & Upland & Natural & None \\
\hline Shawnee & 2012,2014 & Nebraska & Upland & Bred cultivar & $\begin{array}{l}\text { Selection from CIR for high digestibility (IVDMD) } \\
\text { and yield in Nebraska }\end{array}$ \\
\hline Summer & 2012,2014 & South Dakota & Upland & Bred cultivar & $\begin{array}{l}\text { Selection for early flowering and rust resistance in } \\
\text { South Dakota }\end{array}$ \\
\hline Sunburst & 2012,2014 & South Dakota & Upland & Bred cultivar & Selection for large seed size in South Dakota \\
\hline Kanlow & 2012 & Oklahoma & Lowland & Natural & None \\
\hline Kanlow N2 & 2012,2014 & Nebraska & Lowland & Breeding & $\begin{array}{l}\text { Selection from Kanlow for winter survival, biomass } \\
\text { yield and quality }\end{array}$ \\
\hline Summer-Late-Mat. C2 & 2012, 2014 & Nebraska & Upland & Breeding & Two cycles of selection for late flowering from Summer \\
\hline $\mathrm{K} \times \mathrm{S}$ HP1 NETO2 C2 & 2012,2014 & Nebraska & Hybrid & Bred cultivar & $\begin{array}{l}\text { Selection for biomass yield from Kanlow } x \text { Summer } \\
(K \times S) \text { hybrids }\end{array}$ \\
\hline NE 2010 8X HYLD-HDMD C1 & 2012 & Nebraska & Upland & Breeding & $\begin{array}{l}\text { Selection for biomass yield and IVDMD from three } \\
\text { upland populations }\end{array}$ \\
\hline CIR C4 & 2012,2014 & Nebraska & Upland & Breeding & $\begin{array}{l}\text { Four cycles of selection for high biomass yield and high } \\
\text { IVDMD from CIR }\end{array}$ \\
\hline Liberty $(\mathrm{K} \times \mathrm{S}$ HP1 NETO2 C1) & 2012,2014 & Nebraska & Hybrid & Breeding & $\begin{array}{l}\text { Selection for high biomass yield and other traits from } \\
K \times S \text { hybrids }\end{array}$ \\
\hline $\mathrm{K} \times \mathrm{S}$ HP1 High Yield $\mathrm{C} 1$ & 2012 & Nebraska & Hybrid & Breeding & $\begin{array}{l}\text { Selection for high biomass yield and other traits from } \\
\mathrm{K} \times \mathrm{S} \text { hybrids }\end{array}$ \\
\hline Kanlow N1 Late Mat-High Yield & 2012 & Nebraska & Lowland & Breeding & $\begin{array}{l}\text { Selection for high biomass yield and late flowering from } \\
\text { Kanlow N1 }\end{array}$ \\
\hline Kanlow N1 Early Mat-High Yield & 2012 & Nebraska & Lowland & Breeding & $\begin{array}{l}\text { Selection for high biomass yield and early flowering } \\
\text { from Kanlow N1 }\end{array}$ \\
\hline WS-10L & 2014 & Wisconsin & Lowland & Breeding & Selection for winter survivorship from Kanlow \\
\hline WS-11L Syn2 & 2014 & Wisconsin & Lowland & Breeding & $\begin{array}{l}\text { Selection for winter survivorship from various lowland } \\
\text { accessions }\end{array}$ \\
\hline WS-12L & 2014 & Wisconsin & Lowland & Breeding & $\begin{array}{l}\text { Selection for winter survivorship from various lowland } \\
\text { accessions }\end{array}$ \\
\hline WS-12L Syn2 & 2014 & Wisconsin & Lowland & Breeding & $\begin{array}{l}\text { Selection for winter survivorship from various lowland } \\
\text { accessions }\end{array}$ \\
\hline WS-13LU44 & 2014 & Wisconsin & Upland & Breeding & $\begin{array}{l}\text { Selection for late flowering and tall plants from WS4U } \\
\text { in Wisconsin }\end{array}$ \\
\hline WS-13LU44B & 2014 & Wisconsin & Upland & Breeding & $\begin{array}{l}\text { Selection for late flowering and tall plants from WS4U } \\
\text { in Wisconsin }\end{array}$ \\
\hline WS-13LUDLP & 2014 & Wisconsin & Upland & Breeding & $\begin{array}{l}\text { Selection for late flowering and tall plants from WS4U } \\
\text { in Wisconsin }\end{array}$ \\
\hline WS-13LUL10 & 2014 & Wisconsin & Upland & Breeding & $\begin{array}{l}\text { Selection for late flowering and tall plants from WS4U } \\
\text { in Wisconsin }\end{array}$ \\
\hline WS4U & 2014 & NC USA & Upland & Breeding & Broad tetraploid germplasm pool (Casler et al., 2006) \\
\hline WS8U & 2014 & NC USA & Upland & Breeding & Broad octoploid germplasm pool (Casler et al., 2006) \\
\hline ILSW-KG2B & 2014 & Kansas & Lowland & Breeding & $\begin{array}{l}\text { Selection for survivorship and high plant biomass from } \\
\text { Kanlow }\end{array}$ \\
\hline
\end{tabular}

${ }^{\text {a }}$ Planted in 2012, 2014, or both

${ }^{\mathrm{b}}$ Origin of natural population or location of the breeding program $(\mathrm{NC}$, north central)

${ }^{\mathrm{c}}$ Upland ecotype, lowland ecotype, or selected population from within Kanlow $\times$ Summer $(\mathrm{K} \times \mathrm{S})$ hybrids

${ }^{\mathrm{d}}$ Natural, natural population; bred cultivar, cultivar developed by breeding and selection, then released; breeding, unreleased breeding population from USDA Lincoln, NE; USDA Madison, WI; or University of Illinois (details in the last column)

2014 plantings. All contrasts were computed for each individual trial-year, after which they were combined over years and trials following verification that results were largely homogeneous across years and trials. Data presentations were focused largely on pooled results across all trial-years within each of the 13 locations.

The relationship between $\mathrm{N}$ removal and biomass yield was quantified by linear regression for each species-locationplanting year combination (42 total field trials; 23 for switchgrass and 19 for big bluestem). Slopes of these regressions, representing $\mathrm{N}$ demand $\left(\mathrm{kg} \mathrm{N} \mathrm{Mg}^{-1} \mathrm{DM}\right)$, were analyzed by linear mixed models with species, location, and year as fixed effects. Increased $\mathrm{N}$ demand, as represented by an increased slope of these linear regressions, is analogous to decreased internal N-use efficiency, iNUE [20], i.e., the change in nitrogen removed by harvest per unit increase in dry biomass yield.

Finally, an attempt was made to relate mean $\mathrm{N}$ removal and $\mathrm{N}$ demand to soil characteristics of the 13 sites, which were highly variable and are shown in Supplemental Table 1 [21]. Soil characteristics were taken from the USDA-NRCS Web 
Table 3 Names, origins, and breeding histories of big bluestem populations planted in 2012 or 2014 experiments

\begin{tabular}{|c|c|c|c|c|}
\hline Population & Year $^{\mathrm{a}}$ & Origin $^{b}$ & Type $^{\mathrm{c}}$ & Breeding history \\
\hline Rountree & 2012,2014 & Iowa & Natural & None \\
\hline Goldmine & 2012,2014 & Nebraska & $\begin{array}{l}\text { Bred } \\
\text { cultivar }\end{array}$ & $\begin{array}{l}\text { Selection for high yield and digestibility (IVDMD) from Kaw, three breeding } \\
\text { cycles }\end{array}$ \\
\hline Bonanza & 2012,2014 & Nebraska & $\begin{array}{l}\text { Bred } \\
\quad \text { cultivar }\end{array}$ & Selection for high yield and digestibility from Pawnee, three breeding cycles \\
\hline Kaw & 2012,2014 & Kansas & $\begin{array}{l}\text { Bred } \\
\quad \text { cultivar }\end{array}$ & Selection for tall and leafy plants, medium to late flowering \\
\hline Niagara & 2012 & New York & Natural & None \\
\hline Sunnyview & 2012 & $\begin{array}{l}\text { South } \\
\text { Dakota }\end{array}$ & $\begin{array}{l}\text { Bred } \\
\quad \text { cultivar }\end{array}$ & Selection for plant vigor, leaf rust, leafiness, and large seed size \\
\hline Champ & 2012,2014 & Nebraska & $\begin{array}{l}\text { Bred } \\
\text { cultivar }\end{array}$ & Selection for high crown diameter and large seed size \\
\hline Kaw HYLD-HDMD C5 & 2012 & Nebraska & Breeding & Selection for high yield and digestibility from Kaw, five breeding cycles \\
\hline $\begin{array}{l}\text { Pawnee HYLD-HDMD } \\
\quad \text { C5 }\end{array}$ & 2012 & Nebraska & Breeding & Selection for high yield and digestibility from Pawnee, five breeding cycles \\
\hline Bamboo C1 & 2012 & Nebraska & Breeding & Plants from HZ5 collections with thick, coarse stems (bamboo appearance) \\
\hline MW5A C1 & 2012,2014 & Nebraska & Breeding & Broad germplasm pool representing USDA hardiness zone $5 \mathrm{a}$ in the NC USA \\
\hline MW5B C1 & 2012,2014 & Nebraska & Breeding & Broad germplasm pool representing USDA hardiness zone $5 \mathrm{~b}$ in the NC USA \\
\hline WBB-11L Syn2 & 2014 & Wisconsin & Breeding & Selection for late flowering and high plant biomass from broad germplasm pool \\
\hline WBB-12L Syn1 & 2014 & Wisconsin & Breeding & Selection for late flowering and high plant biomass from broad germplasm pool \\
\hline WBB-12L Syn2 & 2014 & Wisconsin & Breeding & Selection for late flowering and high plant biomass from broad germplasm pool \\
\hline WBB-12LLOK & 2014 & Wisconsin & Breeding & Selection for late flowering and high plant biomass from broad germplasm pool \\
\hline
\end{tabular}

${ }^{\text {a }}$ Planted in 2012, 2014, or both

${ }^{\mathrm{b}}$ Origin of natural population or location of the breeding program

${ }^{\mathrm{c}}$ Natural, natural population; bred cultivar, cultivar developed by breeding and selection, then released; breeding, unreleased breeding population from USDA Lincoln, NE, or USDA Madison, WI, as noted in the third column

Soil Survey [21]: cation exchange capacity, electrical conductivity, available water storage, and soil texture (percentages of sand, silt, and clay). Soil samples, taken to a depth of $0.7 \mathrm{~m}$ at the time of planting, were analyzed by the University of Wisconsin Soil and Forage Lab [22] for total nitrogen [23], Bray $1 \mathrm{P}$ and $\mathrm{K}$ [24], $\mathrm{pH}$ [25], and OM [26]. Relationships of all soil variables to mean $\mathrm{N}$ removal values and to $\mathrm{N}$ demand were analyzed by simply correlation coefficients and by multiple regression analysis using forward stepwise regression.

\section{Results}

Variation among cultivars or populations was significant for nearly all locations and establishment years (Table 4). There was a slight tendency for lower significance levels (higher $p$ values) for big bluestem compared with switchgrass at a few locations. This was probably a reflection on the smaller number of populations, with fewer degrees of freedom and lower power, combined with less overall effort on breeding big bluestem during the past 30 years, compared with switchgrass.

The path analysis of $\mathrm{N}$ removal was homogeneous across locations and establishment years, so Fig. 1 shows the results pooled across all locations and years. Biomass yield and $\mathrm{N}$ concentration were negatively correlated with each other, as expected for at least a partial dilution effect. Both $\mathrm{N}$ concentration and biomass yield had strong positive effects on $\mathrm{N}$ removal with biomass yield having a 25 to $45 \%$ higher impact than $\mathrm{N}$ concentration.

Most of the GE interactions associated with biomass yield were associated with differences in hardiness zone, specifically hardiness zones $3 / 4$ vs. 5/6 [8]. There were few GE interactions associated with locations within these two groups of hardiness zones and few GE interactions associated with repeated years of harvesting or years of establishment (2012 vs. 2014). Therefore, the contrast analyses for $\mathrm{N}$ concentration and removal, which are focused on genetic responses to selection and population improvement, were pooled across locations and establishment years within the two groups of hardiness zones (HZ $3 / 4$ vs. HZ 5/6). As such, the biologically meaningful GE interactions can be seen as differential selection responses in Fig. 2.

Each of the ten contrast comparisons for biomass yield were significant $(p<0.05)$, with eight positive and two negative responses (Fig. 2). Breeding for increased biomass yield of upland ecotypes of switchgrass significantly improved biomass yield within all plant hardiness zones. Because the 
Table $4 \quad p$ values for biomass yield, nitrogen concentration, and nitrogen removal measured on cultivars and experimental populations of two species established at up to 22 locations in either 2012 or 2014 seeding years

\begin{tabular}{|c|c|c|c|c|c|c|c|}
\hline \multirow[b]{2}{*}{ Year } & \multirow[b]{2}{*}{ Location $^{\mathrm{a}}$} & \multicolumn{3}{|l|}{ Big bluestem } & \multicolumn{3}{|l|}{ Switchgrass } \\
\hline & & Biomass yield & Nitrogen conc. & Nitrogen removal & Biomass yield & Nitrogen conc. & Nitrogen removal \\
\hline 2012 & Grand Rapids, MN & $<0.01$ & $<0.01$ & 0.01 & $<0.01$ & $<0.01$ & $<0.01$ \\
\hline 2014 & Grand Rapids, MN & $<0.01$ & $<0.01$ & 0.04 & $<0.01$ & $<0.01$ & $<0.01$ \\
\hline 2012 & Spooner, WI & $<0.01$ & 0.31 & $<0.01$ & 0.01 & $<0.01$ & 0.01 \\
\hline 2014 & Spooner, WI & $\mathrm{ND}^{\mathrm{b}}$ & ND & ND & 0.03 & 0.66 & 0.03 \\
\hline 2012 & Marshfield, WI & $<0.01$ & $<0.01$ & $<0.01$ & $<0.01$ & $<0.01$ & $<0.01$ \\
\hline 2012 & Brookings, SD & $\mathrm{ND}$ & ND & ND & $<0.01$ & $<0.01$ & $<0.01$ \\
\hline 2012 & Chatham, MI & $<0.01$ & $<0.01$ & 0.01 & $<0.01$ & $<0.01$ & $<0.01$ \\
\hline 2014 & Chatham, MI & ND & ND & ND & $<0.01$ & 0.16 & 0.06 \\
\hline 2012 & Arlington, WI & 0.04 & 0.18 & $<0.01$ & $<0.01$ & $<0.01$ & $<0.01$ \\
\hline 2012 & Ames, IA & 0.05 & 0.33 & 0.07 & $<0.01$ & $<0.01$ & $<0.01$ \\
\hline 2014 & Ames, IA & 0.21 & 0.09 & 0.71 & $<0.01$ & 0.01 & $<0.01$ \\
\hline 2012 & Mead, NE & 0.12 & 0.04 & 0.23 & $<0.01$ & $<0.01$ & $<0.01$ \\
\hline 2014 & Mead, NE & 0.31 & 0.79 & 0.78 & $<0.01$ & $<0.01$ & 0.01 \\
\hline 2012 & Urbana, IL & 0.04 & $<0.01$ & 0.27 & $<0.01$ & $<0.01$ & $<0.01$ \\
\hline 2014 & Urbana, IL & 0.03 & $<0.01$ & 0.18 & $<0.01$ & $<0.01$ & 0.06 \\
\hline 2012 & West Lafayette, IN & $<0.01$ & $<0.01$ & $<0.01$ & $<0.01$ & $<0.01$ & $<0.01$ \\
\hline 2014 & West Lafayette, IN & $<0.01$ & 0.19 & 0.16 & $<0.01$ & $<0.01$ & $<0.01$ \\
\hline 2012 & Columbia, MO & $<0.01$ & 0.30 & 0.64 & $<0.01$ & 0.19 & $<0.01$ \\
\hline 2014 & Columbia, MO & $<0.01$ & 0.08 & 0.08 & $<0.01$ & $<0.01$ & $<0.01$ \\
\hline 2012 & South Charleston, $\mathrm{OH}$ & $<0.01$ & $<0.01$ & 0.02 & 0.22 & $<0.01$ & 0.12 \\
\hline 2014 & South Charleston, $\mathrm{OH}$ & ND & ND & ND & $<0.01$ & 0.03 & $<0.01$ \\
\hline 2012 & State College, PA & $<0.01$ & $<0.01$ & 0.33 & $<0.01$ & $<0.01$ & $<0.01$ \\
\hline 2014 & State College, PA & 0.45 & 0.92 & 0.97 & $<0.01$ & $<0.01$ & $<0.01$ \\
\hline
\end{tabular}

${ }^{\mathrm{a}}$ Locations are sorted by plant hardiness zone: PHZ $3 \mathrm{~b}$ on top to PHZ $6 \mathrm{~b}$ on bottom

${ }^{\mathrm{b}} N D$ no data due to failed establishment or to severe lodging that prevented a yield measurement

lowland and $\mathrm{K} \times \mathrm{S}$ strains of switchgrass were still green and actively growing at the time of killing frost, they had not yet completed their annual life cycle for the locations within plant hardiness zones 3 and 4, reducing their potential for biomass accumulation. As such, selection responses for biomass yield within these two groups were negative, while gains in biomass yield were significant within plant hardiness zones 5 and 6 , where these populations are normally adapted and they were able to complete their annual life cycle before killing frost. Results for big bluestem were intermediate between the upland switchgrass populations and the lowland or $\mathrm{K} \times \mathrm{S}$ populations: significant gains for both hardiness regions, but reduced for the northern regions where big bluestem had less time to complete its annual life cycle.

As expected, based on the negative correlations between biomass yield and $\mathrm{N}$ concentration, responses for $\mathrm{N}$ concentration were generally in the opposite direction as observed for biomass yield, with seven significant responses (five negative and two positive; Fig. 2). The significant increases in $\mathrm{N}$ concentration of the lowland and $\mathrm{K} \times \mathrm{S}$ in plant hardiness zones 3 and 4 was due to their late flowering nature and the inability to complete their annual life cycle, which includes recycling tissue $\mathrm{N}$ to belowground storage tissues. Contrast comparisons for $\mathrm{N}$ removal closely paralleled those for biomass yield in seven of ten cases (five positive and two negative), with partial attenuation of responses due to the negative correlation between biomass yield and $\mathrm{N}$ concentration. This partial attenuation can also be observed in the average absolute responses to selection as a percentage of the unselected controls, which were $38 \%$ for biomass yield and $25 \%$ for $\mathrm{N}$ removal.

Thirty-two of the 42 linear regressions of $\mathrm{N}$ removal on biomass yield were significant $(p<0.05)$, with nine nonsignificant values and one negative value (Table 5; Fig. 3). Nitrogen demand was highly variable, ranging from -1.7 to $6.8 \mathrm{~kg} \mathrm{~N}$ for each megagram increase in biomass yield. There was no significant difference between big bluestem and switchgrass. The two establishment years were significantly different for $\mathrm{N}$ demand $(p<0.01)$, with means of 2.3 and $3.4 \mathrm{~kg} \mathrm{~N} \mathrm{Mg}^{-1} \mathrm{DM}$ for 2012 and 2014, respectively. Locations were highly variable for $\mathrm{N}$ demand, with mean 


\section{Big Bluestem}

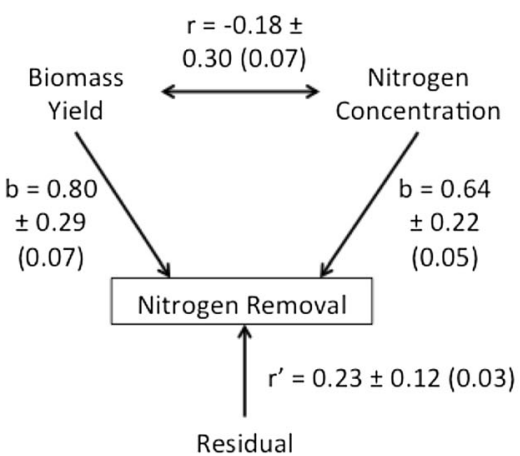

Fig. 1 Path analysis diagrams for switchgrass and big bluestem: standardized partial regression coefficients (direct effects) of biomass yield and nitrogen concentration on nitrogen removal, correlation

values ranging from 0.4 to $4.8 \mathrm{~kg} \mathrm{~N} \mathrm{Mg}^{-1} \mathrm{DM}$, but this variability was not associated with plant hardiness zone (Fig. 4). These differences were significant $(p<0.01)$ and Fig. 4 shows that there was some level of consistency or predictability for $\mathrm{N}$ demand between the 2012 and 2014 establishment years. However, none of the soil chemical or physical characteristics explained a significant portion of variability for either mean $\mathrm{N}$ removal or $\mathrm{N}$ demand across locations,

\section{Switchgrass}

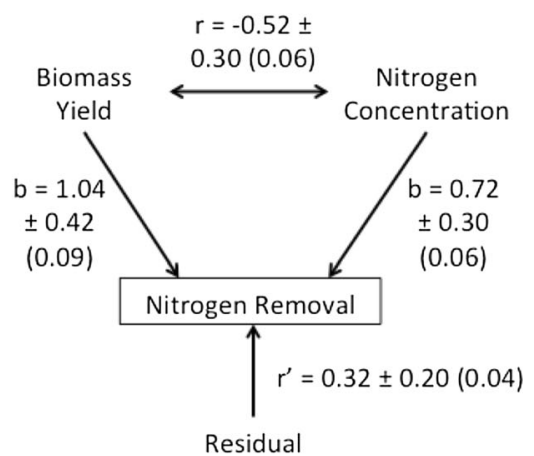

coefficients between biomass yield and nitrogen concentration, and residuals. All values represent the mean over all trial-years for each species

either individually or from the multiple regression analyses; the highest proportion of variability explained was $<0.25$. Specifically, neither $\mathrm{N}$ removal nor $\mathrm{N}$ demand was related to total $\mathrm{N}$ concentration in the soil for either switchgrass or big bluestem $\left(r^{2}<0.02\right)$. Despite the large range in mean soil $\mathrm{N}$ (663 to $1994 \mathrm{ppm}$ ), this was a strong indication that the use of nitrogen fertilizer in this experiment resulted in non-Nlimiting conditions.
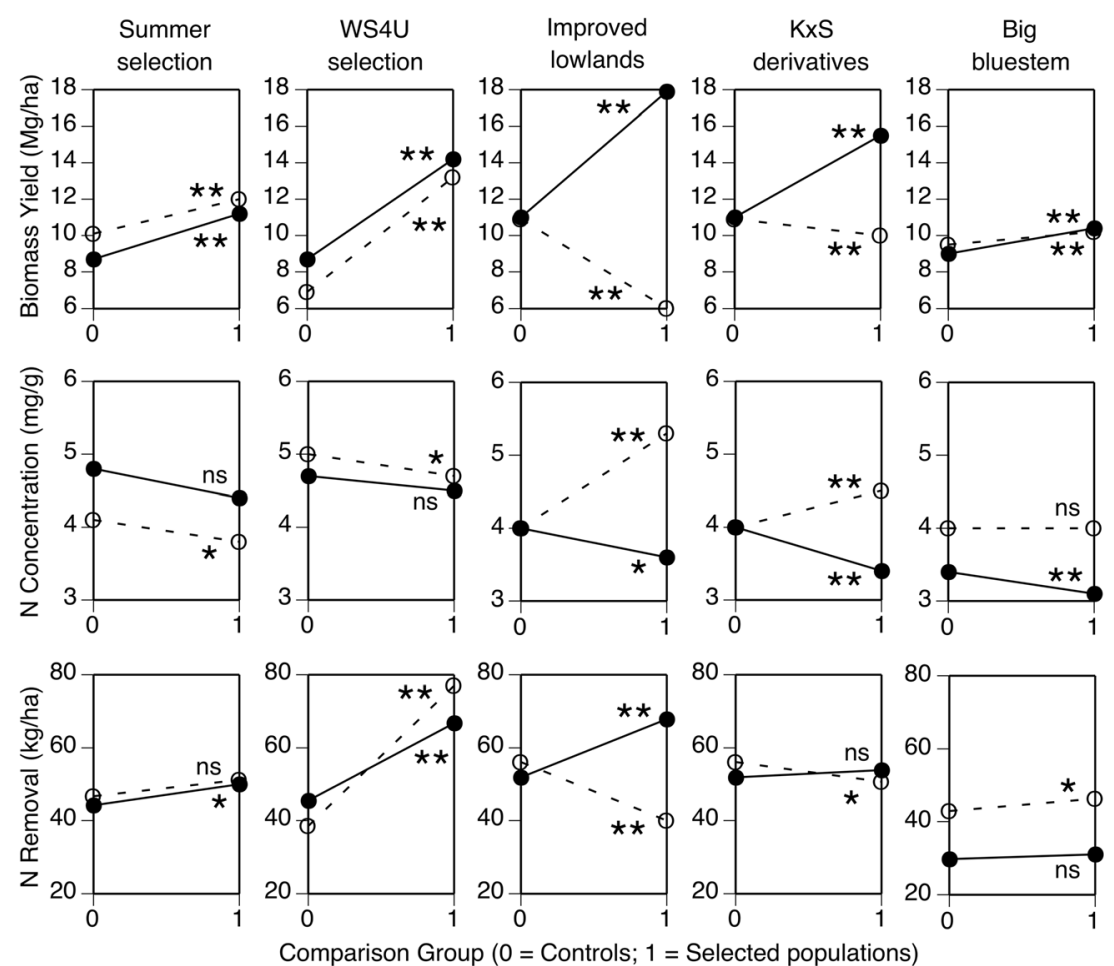

Fig. 2 Responses to selection for increased biomass yield of switchgrass or big bluestem germplasm ( $x$-axis: $0=$ unselected parent population or cultivars; 1 = progeny populations selected for increased biomass yield). The five columns, each representing a different set of control vs. selected populations, are described in detail in the text and in Tables 2 and 3. Open circles and dashed lines represent the mean of all trials located in USDA plant hardiness zones 3 and 4; closed circles and solid lines represent the mean of all trials located in USDA plant hardiness zones 5 and 6 ; *,**, and ns represent significance at 0.05 or 0.01 , or non-significance, respectively, of the selection responses ( 0 vs. 1 on the $x$-axis) 
Table 5 Statistics for the linear regressions of nitrogen removal $\left(\mathrm{kg} \mathrm{ha}^{-1}\right)$ on biomass yield $\left(\mathrm{Mg} \mathrm{ha}^{-1}\right)$ for 42 big bluestem or switchgrass trials, computed from population means over years

\begin{tabular}{|c|c|c|c|c|c|c|c|c|c|}
\hline \multirow[b]{2}{*}{ Year } & \multirow[b]{2}{*}{ Location $^{\mathrm{a}}$} & \multicolumn{4}{|c|}{ Big bluestem } & \multicolumn{4}{|c|}{ Switchgrass } \\
\hline & & $r^{2}$ & \multicolumn{3}{|c|}{$\mathrm{kg} \mathrm{N} \mathrm{Mg}^{-1} \mathrm{DM}$} & $r^{2}$ & \multicolumn{3}{|c|}{$\mathrm{kg} \mathrm{N} \mathrm{Mg}^{-1} \mathrm{DM}$} \\
\hline 2012 & Grand Rapids, MN & 0.80 & 2.78 & 0.43 & $<0.01$ & 0.90 & 5.66 & 0.41 & $<0.01$ \\
\hline 2014 & Grand Rapids, MN & 0.58 & 4.11 & 1.18 & 0.01 & 0.94 & 6.81 & 0.40 & $<0.01$ \\
\hline 2012 & Spooner, WI & 0.80 & 2.65 & 0.42 & $<0.01$ & 0.41 & 3.25 & 0.45 & $<0.01$ \\
\hline 2014 & Spooner, WI & $\mathrm{ND}^{\mathrm{b}}$ & ND & ND & ND & 0.84 & 4.92 & 0.47 & $<0.01$ \\
\hline 2012 & Marshfield, WI & 0.78 & 3.29 & 0.56 & $<0.01$ & 0.79 & 3.23 & 0.37 & $<0.01$ \\
\hline 2012 & Brookings, SD & ND & ND & ND & ND & 0.44 & 1.65 & 0.41 & $<0.01$ \\
\hline 2012 & Chatham, MI & 0.10 & 1.53 & 1.46 & 0.32 & 0.13 & -1.72 & 1.06 & 0.12 \\
\hline 2014 & Chatham, MI & $\mathrm{ND}$ & ND & ND & ND & 0.03 & 0.79 & 1.11 & 0.49 \\
\hline 2012 & Arlington, WI & 0.73 & 4.81 & 0.93 & $<0.01$ & 0.34 & 3.72 & 1.17 & $<0.01$ \\
\hline 2012 & Ames, IA & 0.82 & 3.62 & 0.53 & $<0.01$ & 0.26 & 3.16 & 1.25 & 0.02 \\
\hline 2014 & Ames, IA & 0.44 & 2.63 & 1.00 & 0.03 & 0.89 & 3.70 & 0.31 & $<0.01$ \\
\hline 2012 & Mead, NE & 0.73 & 2.94 & 0.56 & $<0.01$ & 0.10 & 1.13 & 0.78 & 0.16 \\
\hline 2014 & Mead, NE & 0.58 & 5.71 & 1.62 & 0.01 & 0.53 & 2.38 & 0.52 & $<0.01$ \\
\hline 2012 & Urbana, IL & 0.50 & 2.27 & 0.72 & 0.01 & 0.49 & 2.18 & 0.50 & $<0.01$ \\
\hline 2014 & Urbana, IL & 0.28 & 3.45 & 1.83 & 0.09 & 0.81 & 3.39 & 0.39 & $<0.01$ \\
\hline 2012 & West Lafayette, IN & 0.73 & 2.36 & 0.46 & $<0.01$ & 0.41 & 2.18 & 0.62 & $<0.01$ \\
\hline 2014 & West Lafayette, IN & 0.56 & 1.79 & 0.53 & 0.01 & 0.43 & 1.51 & 0.41 & $<0.01$ \\
\hline 2012 & Columbia, MO & 0.25 & 0.50 & 0.27 & 0.10 & 0.00 & 0.04 & 0.27 & 0.89 \\
\hline 2014 & Columbia, MO & 0.29 & 0.81 & 0.42 & 0.09 & 0.75 & 1.36 & 0.18 & $<0.01$ \\
\hline 2012 & South Charleston, $\mathrm{OH}$ & 0.26 & 1.78 & 0.96 & 0.09 & 0.39 & 2.92 & 1.09 & 0.02 \\
\hline 2014 & South Charleston, $\mathrm{OH}$ & ND & ND & ND & ND & 0.80 & 4.69 & 0.55 & $<0.01$ \\
\hline 2012 & State College, PA & 0.00 & -0.05 & 0.34 & 0.87 & 0.18 & 1.35 & 0.63 & 0.05 \\
\hline 2014 & State College, PA & 0.81 & 3.60 & 0.58 & $<0.01$ & 0.78 & 2.77 & 0.34 & $<0.01$ \\
\hline 2012 & Overall mean & 0.61 & 1.57 & 0.40 & $<0.01$ & 0.27 & 2.08 & 0.76 & 0.01 \\
\hline 2014 & Overall mean & 0.60 & 2.10 & 0.58 & $<0.01$ & 0.79 & 3.00 & 0.37 & $<0.01$ \\
\hline
\end{tabular}

${ }^{\mathrm{a}}$ Locations are sorted by plant hardiness zone: PHZ $3 \mathrm{~b}$ on top to PHZ $6 \mathrm{~b}$ on bottom

${ }^{\mathrm{b}} N D$ no data due to failed establishment

Fig. 3 Scatterplots and linear regressions of nitrogen removal as a function of biomass yield for big bluestem and switchgrass, illustrating the range of responses. Each panel shows the regressions with the minimum or maximum $\mathrm{N}$ demand within each establishment year (2012 and 2014), with regression statistics shown in Table 3
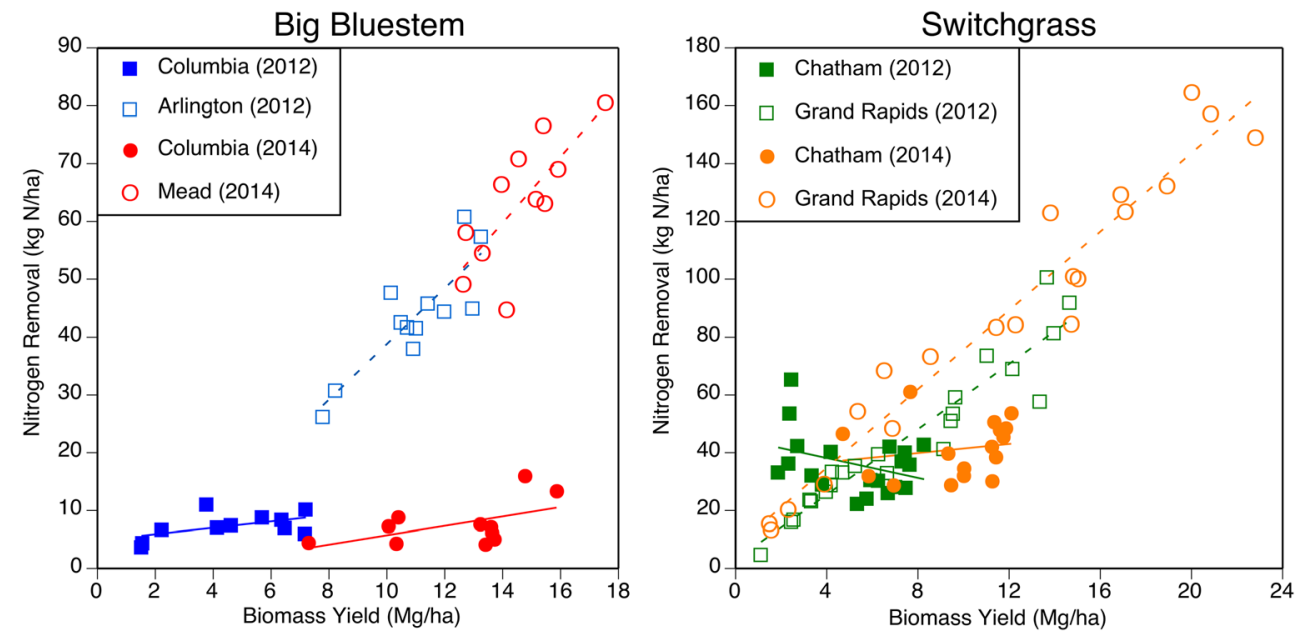


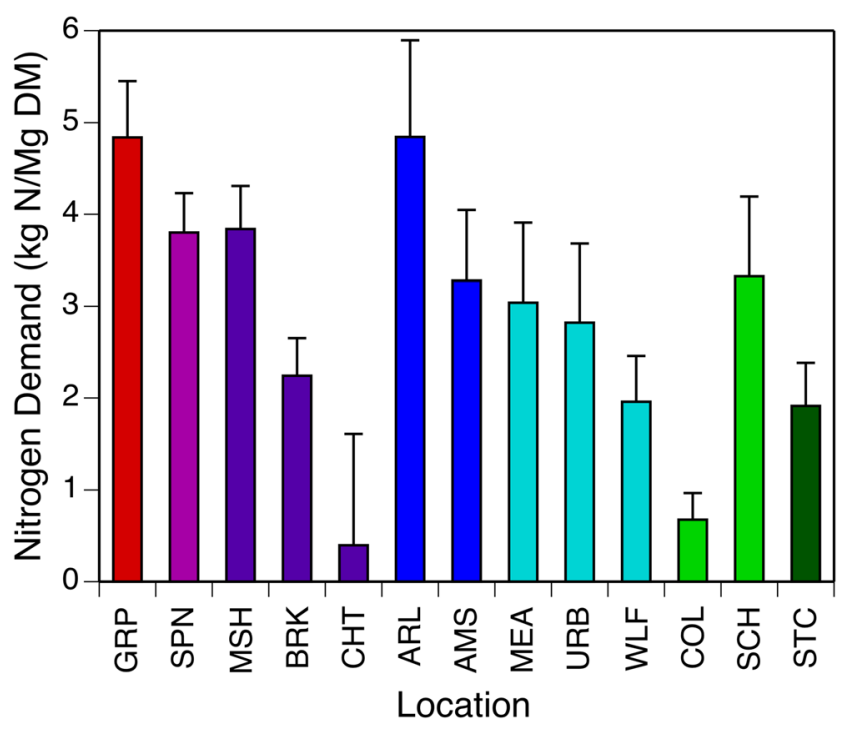

Fig. 4 Mean nitrogen demand for 13 field locations, as measured by the slope of linear regressions of nitrogen removal on biomass yield, averaged across two species and two establishment years. Locations are sorted as shown in Table 1, from hardiness zone $3 \mathrm{~b}$ (left) to $6 \mathrm{~b}$ (right) and each color represents a specific plant hardiness zone (GRP, Grand Rapids, MN; SPN, Spooner, WI; MSH, Marshfield, WI; BRK, Brookings, SD; CHT, Chatham, MI; ARL, Arlington, WI; AMS, Ames, IA; MEA, Mead, NE; URB, Urbana, IL; WLF, West Lafayette, IN; COL, Columbia, MO; $\mathrm{SCH}$, South Charleston, OH; STC, State College, PA)

\section{Discussion}

Nitrogen is essential to life, being one of the most important constituents of amino acids, proteins, and enzymes. For this reason, breeding for increased $\mathrm{N}$ content has often been an objective of forage breeding programs aimed at developing forage crops with increased protein content [27-29]. Nitrogen concentration has a moderate to high heritability and it is relatively easy and rapid to achieve increases in protein concentration of both grasses and legumes [27-29].

Dedicated biomass crops represent a significant departure from this concept because $\mathrm{N}$ removed in the biomass is largely wasted for future use, except as a component of biochar, a byproduct of biomass pyrolysis, which can be used as a source of nutrients for future crops [30]. Essentially, $\mathrm{N}$ has little or no value for conversion of biomass to energy, except as a component of fertilizer co-products from the conversion process. Delayed harvesting is one of the principal shortterm strategies to mitigate $\mathrm{N}$ loss from bioenergy cropping systems. Perennial energy grasses remobilize tissue $\mathrm{N}$ in response to decreased photoperiod and temperature during autumn [31]. Delaying harvest until after killing frost can result in significant reductions in tissue $\mathrm{N}$, but additional significant reductions continue to occur during winter, even though active translocation has ceased [32,33]. Some of these winter losses occur through leaf loss as litter, some of which are retained in the field $[34,35]$.
Historically, switchgrass and big bluestem have been bred under conditions where $\mathrm{N}$ has been non-limiting, e.g., conditions similar to the soils and production conditions utilized in this study. Under these conditions, increases in biomass yield have led to a clear increase in $\mathrm{N}$ demand, essentially a decrease in iNUE, as defined by [20]. While the increases in $\mathrm{N}$ demand were highly variable across locations and somewhat variable between different trials within each location, they were nearly always positive and significant, resulting in an overall mean of $2.2 \mathrm{~kg} \mathrm{~N} \mathrm{Mg}^{-1} \mathrm{DM}$. While additional delays in harvesting, well after killing frost, will likely attenuate some of this increased $\mathrm{N}$ demand, it is important to realize that largescale production of biomass from perennial energy grasses will require "just-in-time" harvesting approaches, where biomass is stored in the field and harvested over many months on an "as needed" basis [36]. Ideally, producers could rotate which fields are harvested early vs. late, thereby practicing a form of $\mathrm{N}$ conservation by rotating those fields that suffer significant nitrogen losses in any given year. Studies have shown that switchgrass biomass can be maintained at a high level on high fertility soils for up to 2 or 3 years after fertilization [37, 38], implying that an occasional or cyclic $\mathrm{N}$ loss from the system could be tolerated. However, this is a very idealistic scenario that increases the level of complication in a biomass production operation, increasing the likelihood that it will not become a standard operating procedure.

Alternatively, in the longer term, breeding programs for perennial energy grasses should begin to focus on improving N-use efficiency as a routine part of the breeding objective. For these two species, the negative genetic correlation between biomass yield and tissue $\mathrm{N}$ concentration is simply not large enough to rely on correlated responses to selection. While tissue $\mathrm{N}$ concentration tends to decline with selection for biomass yield, these decreases are insufficient to offset the relatively high rates of gain (and notable successes) from breeding for increased biomass yield. Rather, tissue $\mathrm{N}$ concentration should become part of the selection criterion, likely as part of a selection index or as a ratio criterion, e.g., biomass yield $\div$ nitrogen concentration $[39,40]$.

Research on sugarcane (Saccharum officinarum L.) has demonstrated genetic variability for iNUE, which is expressed more under low-N compared with high-N conditions [20]. As observed in the present study of switchgrass and big bluestem for $\mathrm{N}$ demand, iNUE was strongly a function of biomass yield in sugarcane. Furthermore, iNUE was positively correlated between low-N and high-N conditions, a phenomenon commonly observed for biomass yield of switchgrass [8,9], suggesting that iNUE is repeatable. While the results of this study suggest that iNUE of both switchgrass and big bluestem has been decreased by selection for increased biomass yield, the results for sugarcane suggest that perhaps this trend can be reversed by directed and focused selection aimed at 
increasing biomass yield and decreasing tissue $\mathrm{N}$ concentration, as suggested above.

Collecting and processing biomass samples within an energy-grass breeding program require a massive time commitment, both for sampling tissue at harvest time and for processing samples during the offseason. The use of near-infrared reflectance spectroscopy (NIRS) is an essential component of this process, allowing breeding programs to process samples more rapidly than can be accomplished if each sample must be analyzed by wet chemistry [18]. Nevertheless, work-loads can be reduced and throughput can be increased if a hand-held NIRS can be adapted to predict tissue $\mathrm{N}$ based on real-time scans made on fresh tissue either at the harvest time or shortly beforehand. The latter would be advantageous because of the time and labor commitment required for harvesting biomass plots. Hand-held or portable NIRS units are capable of predicting chemical constituents of liquids, fruits, grains, and herbage [41-46]. Similar technologies have been used to scan forage-crop canopies to predict $\mathrm{N}$ concentration of standing alfalfa (Medicago sativa L.) or bermudagrass (Cynodon dactylon (L.) Pers.) forage crops, with $r^{2} \approx 0.6[47,48]$. This technology would allow for selections to be made immediately after the biomass harvest, drastically reducing the need for time-sensitive offseason activities, which are often significant sources of stress for project personnel, as well as competition against glasshouse activities focused on establishment of new nurseries to advance the breeding program.

Most of the improved populations evaluated in this study were bred under non-N-limiting conditions, similar to those in the evaluation environments. This is similar to the philosophy of many plant breeding programs, which have often operated under the assumption that the most favorable environments favor expression of genetic variability, favoring the greatest rate of gain [49]. More recent results have demonstrated that the most effective selection for low-input conditions should be made under those same low-input conditions [50-55]. Quantitative genetic theory generally supports this philosophy, suggesting that the heritability and genetic correlation requirements to support indirect selection under high-input conditions are too great to provide a routine advantage compared with direct selection under low-input conditions [56-58].

These conclusions were supported by a switchgrass study in which direct selection under low-input conditions resulted in the greatest gain under those conditions [59]. From a broader perspective, the elimination of $\mathrm{N}$ fertilizer on switchgrass selection nurseries would increase the likelihood of identifying genotypes with enhanced breeding value for the ability to recycle $\mathrm{N}$ efficiently, to utilize $\mathrm{N}$ efficiently, and to scavenge $\mathrm{N}$ from low-N soils. This may even extend to the ability of breeders to identify switchgrass genotypes capable of forming beneficial associations with rhizobacteria or endophytic bacteria that may have growth promotion impacts, such as biological $\mathrm{N}$ fixation, nutrient acquisition, and increased biomass production $[60,61]$. Nutrient acquisition by host plants may also be enhanced by arbuscular mycorrhizal fungi [62]. Because host-microbe associations are under genetic control and heritable, it should be possible to identify genotypes with superior nutrient acquisition ability and nutrientuse efficiency [63-66]. Just as $\mathrm{N}$ fertilization may impair the ability of a soil microbiome to evolve into a diverse community capable of providing these functions [67], it may also limit our ability to break the link between increased biomass yield and increased $\mathrm{N}$ demand.

Acknowledgments We thank Anne Kinzel for her dedication, financial and personnel management, emotional support, and inspiration throughout the duration of the CenUSA project. We also thank Chris Kapp, Michigan State University, Chatham, MI; Roger Hintz, Iowa State University, Ames, IA; Danny England, University of Missouri, Columbia, MO; John McCormick, Ohio State University, Columbus, OH; Joe Crawford, University of Illinois, Urbana, IL; Steve Masterson, USDA-ARS, Lincoln, NE; Matt Myers, USDA-ARS, University Park, PA; Nick Baker, USDA-ARS, Madison, WI; and Joe Halinar, USDAARS, Madison, WI for their expert assistance with planting, plot maintenance and management, data collection, and sample preparation throughout the course of this experiment. We especially thank our former colleague, Kenneth P. Vogel (USDA, retired), for his critical review and comments which helped to improve the clarity of this paper.

Funding Information This research was funded by the Agriculture and Food Research Initiative Competitive Grant No. 2011-68005-30411 from the USDA National Institute of Food and Agriculture (CenUSA).

\section{References}

1. Robertson GP, Hamilton SK, Barham BL, Dale BE, Izaurralde RC, Jackson RD, Landis DA, Swinton SM Thelan KD, Tiedje JM (2017) Cellulosic biofuel contributions to a sustainable energy future: choices and outcomes. Science 356:eaal2324

2. Sanderson MA, Adler PR, Boateng AA, Casler MD, Sarath G (2007) Switchgrass as a biofuels feedstock in the USA. Can J Plant Sci 86:1315-1325

3. Mitchell RB, Schmer MR, Anderson WF, Jin V, Balkcom KS, Kiniry J, Coffin A, White P (2016) Dedicated energy crops and crop residues for bioenergy feedstocks in the central and eastern USA. Bioenergy Res 9:384-398

4. Sprunger CD, Oates LG, Jackson RD, Robertson GP (2017) Plant community composition influences fine root production and biomass allocation in perennial bioenergy cropping systems of the upper Midwest, USA. Biomass Bioenergy 105:248-258

5. Zannone L, Rotili P, Paoletti R, Scotti C (1986) Experimental studies on grass-legume associations. Agronomie 6:931-940

6. Piano E, Annicchiarico P (1995) Interference effects in grass varieties grown as pure stand, complex mixture and binary mixture with white clover. J Agron Crop Sci 174:301-308

7. Casler MD, Vogel KP (2014) Selection for biomass yield in upland, lowland, and hybrid switchgrass. Crop Sci 54:626-636

8. Casler MD, Vogel KP, Lee DK, Mitchell RB, Adler PR, Sulc RM, Johnson KD, Kallenbach RL, Boe AR, Mathison RD, Cassida KA, 
Min DH, Crawford J, Moore KJ (2018) 30 years of progress toward increasing biomass yield of switchgrass and big bluestem. Crop Sci $58: 1242-1254$

9. Casler MD, Sosa S, Hoffman L, Mayton H, Ernst C, Adler PR, Boe AR, Bonos SA (2017) Biomass yield of switchgrass cultivars under high- versus low-input conditions. Crop Sci 57:821-832

10. Johnson LC, Olsen JT, Tetreault H, DeLaCruz A, Bryant J, Morgan TJ, Knapp M, Bello NM, Baer SG, Maricle BR (2015) Intraspecific variation of a dominant grass and local adaptation in reciprocal garden communities along a US Great Plains' precipitation gradient: implications for grassland restoration with climate change. Evol Appl 8:705-723

11. Parrish DJ, Fike JH (2005) The biology and agronomy of switchgrass for biofuels. Crit Rev Plant Sci 24:423-459

12. Erisman JW, van Grinsven H, Leip A, Mosier A, Bleeker A (2010) Nitrogen and biofuels: an overview of the current state of knowledge. Nutr Cycl Agroecosyst 86:211-223

13. Norris MD, Reich PB (2009) Modest enhancement of nitrogen conservation via retranslocation in response to gradients in $\mathrm{N}$ supply and leaf N status. Plant Soil 316:193-204

14. Wullschleger SD, Davis EB, Borsuk ME, Gunderson CA, Lynd LR (2010) Biomass production in switchgrass across the United States: database description and determinants of yield. Agron J 102:11581168

15. Vogel KP, Brejda JJ, Walters DT, Buxton DR (2002) Switchgrass biomass production in the Midwest USA: harvest and nitrogen management. Agron J 94:413-420

16. USDA (2019a) Plant hardiness zone map. https:// planthardinessarsusdagov/PHZMWeb/ Accessed 10 November 2019

17. Association of Seed Analysts (AOSA) (1998) Rules for seed testing. AOSA: Beltsville, MD, USA

18. Vogel KP, Dien BS, Jung HG, Casler MD, Masterson SD, Mitchell RB (2011) Quantifying actual and theoretical ethanol yields for switchgrass strains using NIRS analysis. Bioenergy Res 4:96-110

19. Littell RC, Milliken GA, Stroup WW, Wolfinger RD (1996) SAS system for mixed models. SAS Institute, Inc Cary, NC, USA

20. Robinson N, Fletcher A, Whan A, Critchley C, von Wirén N, Lakshmanan P, Schmidt S (2007) Sugarcane genotypes differ in internal nitrogen use efficiency. Func Plant Biol 34:1122-1129

21. USDA (2019b) USDA-NRCS Web Soil Survey. https:// websoilsurvey.sc.egov.usda.gov/App/HomePage.htm.

22. University of Wisconsin (2019) UW Soil and Forage Lab. https:// uwlabsoilswiscedu/ Accessed 10 November 2019

23. Bremmer JM (1965) Total nitrogen, In Black CA et al (eds) Methods of soil analysis, Part 2. Agronomy. ASA-CSSA-SSSA Monograph No 9 pp1149-1178

24. Bray RH, Kurtz LT (1945) Determination of total, organic, and available forms of phosphorus in soil. Soil Sci 59:39-45

25. Watson ME, Brown JR (1998) pH and lime requirement, In Brown JR (ed) Recommended chemical soil test procedures for the North Central region pp 13-16. NCR Publ No 221, Missouri Agric Exp Stn, Columbia, MO

26. Combs SM, Nathan MV (1998) Soil organic matter, In Brown JR (ed) Recommended chemical soil test procedures for the North Central region pp 57-58. NCR Publ No 221, Missouri Agric Exp Stn, Columbia, $\mathrm{MO}$

27. Clements RJ (1969) Selection for crude protein content in Phalaris tuberosa L. I. Response to selection and preliminary studies on correlated response. Aust J Agric Res 20:643-652

28. Sumberg JE, Murphy RP, Lowe CC (1983) Selection for fiber and protein concentration in a diverse alfalfa population. Crop Sci 23: $11-14$

29. Teuber LR, Phillips DA (1998) Influences of selection method and nitrogen environment on breeding alfalfa for increased forage yield and quality. Crop Sci 28:599-604
30. Biedermann LA, Harpole WS (2013) Biochar and its effects on plant productivity and nutrient cycling: a meta-analysis. GCB Bioenergy 5:202-214

31. Schwartz C, Amasino R (2013) Nitrogen recycling and flowering time in perennial bioenergy crops. Front Plant Sci. https://doi.org/ 10.3389/fpls.2013.00076

32. Kering MK, Butler TJ, Biermacher JT, Mosali J, Guretsky JA (2013) Effect of potassium and nitrogen fertilizer on switchgrass productivity and nutrient removal rates under two harvest systems on a low potassium soil. Bioenergy Res 6:329-335

33. Serapiglia MJ, Boateng AA, Lee DK, Casler MD (2016) Switchgrass harvest time management can impact biomass yield and nutrient content. Crop Sci 56:1970-1980

34. Garten CTJr, Smith JL, Tyler DD, Amonette JE, Bailey VL, Brice DJ, Castro HF, Graham RL, Gunderson CA, Izaurralde RC, Jardine PM, Jastrow JD, Kerley MK, Matamala R, Mayes MA, Metting FB, Miller RM, Moran KK, Post WMIII, Sands RD Schadt CW, Phillips JR, Thomson AM, Vugteveen T, West TO, Wullschleger SD (2010) Intra-annual changes in biomass, carbon, and nitrogen dynamics at 4-year-old switchgrass field trials in west Tennessee, USA. Agric Ecosyst Envt 136:177-184

35. Miesel JR, Jach-Smith LC, Renz MJ, Jackson RD (2017) Distribution of switchgrass (Panicum virgatum L.) aboveground biomass in response to nitrogen addition and across harvest dates. Biomass Bioenergy 100:74-83

36. Shinners KJ, Sabrowsky BK, Studer CL, Nicholson RL (2017) Switchgrass harvest progression in the North-Central USA. Bioenergy Res 10:613-625

37. Lemus R, Parrish DJ, Abaye O (2008) Nitrogen-use dynamics in switchgrass grown for biomass. Bioenergy Res 1:153-162

38. Springer TL (2017) Effect of nitrogen fertilization and residual nitrogen on biomass yield of switchgrass. Bioenergy Res 10:648 656

39. Jahufer MZZ, Casler MD (2017) Application of the Smith-Hazel selection index for improving biomass yield and quality of switchgrass. Crop Sci 55:1212-1222

40. Rowe DE (1995) Characteristics of elite populations selection on ration criterion: I. Traits with equal genetic variances. Crop Sci 35: 425-430

41. Zude M, Pflanz M, Kaprielian C, Aivazian BL (2008) NIRS as a tool for precision horticulture in the citrus industry. Biosyst Eng 99: 455-459

42. Pérez-Marín D, Paz P, Guerrero J, Garrido-Varo A, Sánchez M (2010) Miniature handheld NIR sensor for the on-site non-destructive assessment of post-harvest quality and refrigerated storage behavior in plums. J Food Eng 99:294-302

43. Roza-Delgado B, Garrido-Varo A, Soldado A, Arrojo AG, Valdés MC, Maroto F, Pérez-Marín D (2017) Matching portable NIRS instruments for in situ monitoring indicators of milk composition. Food Control 76:74-81

44. Torres I, Pérez-Marín D, De la Haba M, Sánchez M (2017) Developing universal models for the prediction of physical quality in citrus fruits analysed on-tree using portable NIRS sensors. Biosyst Eng 153:140-148

45. Pasquini C (2018) Near infrared spectroscopy: a mature analytical technique with new perspectives - a review. Anal Chim Acta 1026: 8-36

46. Correia RM, Tosato F, Domingos E, Rodrigues RRT, Aquino LFM, Filgueiras PR, Larcerda VJr, Romão (2018) Portable near infrared spectroscopy applied to quality control of Brazilian coffee. Talanta 176:59-68

47. Post CJ, DeGloria SD, Cherney JH, Mikhailova EA (2007) Spectral measurements of alfalfa/grass fields related to forage properties and species composition. J Plant Nutr 30:1779-1789

48. Zhao D, Starks PJ, Brown MA, Phillips WA, Coleman SA (2007) Assessment of forage biomass and quality parameters of 
bermudagrass using proximal sensing of pasture canopy reflectance. Grassl Sci 53:39-49

49. Bänziger M, Cooper M (2001) Breeding for low input conditions and consequences for participatory plant breeding: examples from tropical maize and wheat. Euphytica 122:503-519

50. Bänziger M, Betrán FJ, Lafitte HR (1997) Efficiency of highnitrogen selection environments for improving maize for lownitrogen target environments. Crop Sci 37:1103-1109

51. Machado AT, Fernandes MS (2001) Participatory maize breeding for low nitrogen tolerance. Euphytica 122:567-573

52. Presterl T, Seitz G, Landbeck M, Thiemt EM, Schmidt W, Geiger HH (2003) Improving nitrogen-use efficiency in European maize: estimation of quantitative genetic parameters. Crop Sci 43:12591265

53. Brancourt-Hulmel M, Heumez E, Pluchard P, Beghin D, Departureaux C, Giraud A, Le Gouis J (2005) Indirect versus direct selection of winter wheat for low-input or high-input levels. Crop Sci 45:1427-1431

54. Dawson JC, Murphy KM, Jones SS (2008) Decentralized selection and participatory approaches in plant breeding for low-input systems. Euphytica 160:143-154

55. Ceccarelli S, Grando S (2009) Participatory plant breeding, In Cereals. Handbook of Plant Breeding, Carena, M, Ed, Springer, NY, USA, 2009, Volume 3, pp 395-414

56. Allen FL, Comstock RE, Rasmussen DC (1978) Optimal environments for yield testing. Crop Sci 18:747-751

57. Rosielle AA, Hamblin J (1981) Theoretical aspects of selection for yield in stress and non-stress environments. Crop Sci 21:943-946

58. Atlin GN, Frey KJ (1989) Breeding crop varieties for low-input agriculture. Amer J Alt Agric 4:53-58

59. Rose LW IV, Das MK, Fuentes RG, Taliaferro CM (2007) Effects of high- vs. low-yield environments on selection for increased biomass yield in switchgrass. Euphytica 156:407-415
60. Farrar K, Bryant D, Cope-Selby N (2014) Understanding and engineering beneficial plant-microbe interactions: plant growth promotion in energy crops. Plant Biotech J 12:1193-1206

61. Takcz A, Poole P (2015) Role of root microbiota in plant productivity. J Exptl Bot 66:2167-2175

62. Hodge A, Storer K (2015) Arbuscular mycorrhiza and nitrogen: implications for individual plants through ecosystems. Plant Soil 386:1-19

63. Lima E, Boddey RM, Döbereiner J (1987) Quantification of biological nitrogen fixation associated with sugar cane using a ${ }^{15} \mathrm{~N}$ aided nitrogen balance. Soil Biol Biochem 19:165-170

64. Urquiaga S, Cruz KHS, Boddey RM (1992) Contribution of nitrogen fixation to sugar cane: Nitrogen-15 and nitrogen balance estimates. Soil Sci Soc Amer J 56:105-114

65. Dong M, Yang Z, Cheng G, Peng L, Xu Q, Xu J (2017) Diversity of the bacterial microbiome in the roots of four Saccharum species: S. spontaneum, S. robustum, S. barberi, and S. officinarum. Front Microbiol 9:267 doi: https://doi.org/10.3389/fmicb.2018.00267

66. Roley SS, Duncan DS, Liang D, Garoutte A, Jackson RD, Tiedje JM, Robertson GP (2018) Associative nitrogen fixation (ANF) in switchgrass (Panicum virgatum) across a nitrogen input gradient. PLoS One 13:e0197320

67. Oates LG, Duncan DS, Sanford GR, Liang C, Jackson RD (2016) Bioenergy cropping systems that incorporate native grasses stimulate growth of plant-associated soil microbes in the absence of nitrogen fertilization. Agric Ecosyst Environ 233:396-403

Publisher's Note Springer Nature remains neutral with regard to jurisdictional claims in published maps and institutional affiliations. 